\title{
Dephosphorylation of tuberous sclerosis complex 2 by serine/threonine protein phosphatase 5
}

\author{
O. M. Malanchuk ${ }^{1,2}$, S. S. Palchevskyy ${ }^{1}$, V. V. Filonenko ${ }^{1}$ \\ ${ }^{1}$ Institute of Molecular Biology and Genetics, National Academy of Sciences of Ukraine \\ 150 Zabolotnogo Str., Kyiv 03680, Ukraine \\ ${ }^{2}$ National Taras Shevchenko University of Kyiv \\ 2 Academician Glushkov av., Kyiv, 03127, Ukraine \\ filonenko@imbg.org.ua
}

\begin{abstract}
We report here for the first time specific interaction between tuberous sclerosis complex 2 (TSC2) and protein phosphatase 5 (PP5) in mammalian cells. We found that the interaction is stronger in exponentially growing and serum stimulated cells when compared to serum starved cells. In addition, we provide the evidence that PP5 dephosphorylates specifically TSC2 at sites, associated with its activation via AMP kinase (AMPK) pathway. Taken together, these results suggest that PP5 exerts negative regulation on TSC1/2 function through dephosphorylation of AMPK-mediated sites.
\end{abstract}

Keywords: protein phosphatase 5, tuberous sclerosis complex 2, dephosphorylation.

Introduction. TSC2 (tuberin) is a $200 \mathrm{kDa}$ tumour suppressor protein, which forms a functional complex with TSC1 (hamartin). In this complex TSC2 is the catalytic subunit possessing GTPase-activating protein (GAP) activity towards Rheb, a Ras family GTPase [2]. Genetic and biochemical data indicate that Rheb functions downstream of TSC 2 and upstream of mTOR (mammalian target of rapamycin [3-5]. Rheb-induced activation of the mTOR pathway stimulates the phosphorylation of two translational regulators, S6K (ribosomal S6 kinase 1) and 4EBP1 (eukaryotic initiation factor $4 \mathrm{E}$ binding protein 1) $[2,6]$. Deregulation of TSC1/TSC2 complex has been implicated in pathogenesis of tuberous sclerosis, an autosomal-dominant disorder, associated with the development of hamartomas in almost every organ, most notably in brain, kidneys, heart, and eyes [1].

(C) O. M. MALANCHUK, S. S. PALCHEVSKYY, V. V. FILONENKO, 2008
The activity of TSC2 is regulated by multiple phosphorylations mediated by diverse protein kinases, including PKB/Akt, RSK1, ERK, MK2, and AMPK [7-10]. Therefore, TSC1/TSC2 complex integrates signals from multiple signalling pathways and influences diverse cellular functions through negative regulation of the mTOR pathway $[8,11,12]$.

Although the mechanisms of TSC2 regulation by protein kinases were studied extensively, little is known so far about phosphotase(s) catalyzing dephosphorylation of this protein. Previously we have reported that serine/threonine protein phosphatase 5 (PP5) is a novel binding partner of TSC2 [13]. Furthermore, we demonstrated that PP5 interacts specifically with TSC2 not only in yeast two-hybrid system, but also in mammalian cells [14]. In order to establish functional link between TSC1/TSC2 and PP5 we studied the protein complex formation in starved cells and in response to serum stimulation. 
Additionally, we tested whether dephosphorylation of TSC2 could be mediated by PP5.

Materials and Methods. Culturing and transfection of $\mathrm{TSC}^{+/+} \mathrm{p} 53^{-/-}$mouse embryonic fibroblasts (MEFs) was described previously in [14]. The production of anti-TSC2 mAbs (D6) is described in [15]. Polyclonal anti-PP5 antibody was purchased from Cell Signaling and anti-Myc $\mathrm{mAb}$ was from «Invitrogen» (USA). Cell lysate preparation, Western blot analysis and immunoprecipitation of TSC2/PP5 protein complex have been performed according to [15]. Recombinant PP5 was purified from insect cells, infected with recombinant baculovirus. Enzymatically active AMPK was presented by Dr M Sanders and Prof. D. Carling, MRC Centre, London.

TSC2 was immunoprecipitated from $\mathrm{TSC}^{+/+} \mathrm{p} 53^{-/}$ MEFs cells lysate $(100 \mu \mathrm{g})$ using antibody (anti-TSC2 mAb D6) coupled to Protein A Sepharose beads. Immunoprecipitates were incubated with $1 \mu$ of AMPK for $30 \mathrm{~min}$ at $37^{\circ} \mathrm{C}$ in a final volume of $25 \mu \mathrm{l}$ of kinase buffer (50 mM HEPES, pH 7.3, $1 \mathrm{mM}$ DTT, $50 \mathrm{mM}$ $\mathrm{NaCl}, 2.5 \mathrm{mM} \mathrm{MgCl}, 0.1 \mathrm{mM}$ ATP, $2.5 \mu \mathrm{Ci}$ of $\left.\left[\gamma-{ }^{32} \mathrm{P}\right] \mathrm{ATP}\right)$. Then, beads were washed in phosphatase assay buffer (60 mM Tris-HCl, $\mathrm{pH}$ 7.6, $1 \mathrm{mM}$ EDTA, $1 \mathrm{mM}$ EGTA, $0.1 \% \quad \beta$-mercaptoethanol). PP5 phosphatase assay was performed in a reaction mixture $(25 \mu \mathrm{l})$ containing $1 \mu \mathrm{g}$ of recombinant PP5 and $200 \mu \mathrm{M}$ of arachidonic acid at $30{ }^{\circ} \mathrm{C}$ for 2 hrs. Reaction was terminated by the addition of SDS-PAGE sample buffer. Samples were boiled for $4 \mathrm{~min}$ and subjected to SDS-PAGE. The level of TSC2 phosphorylation was measured by autoradiography.

Results and Discussion. To analyze the interaction between TSC2 and PP5 in cells under different growth conditions, we have applied the immunoprecipitation assay followed by Western blotting. Initially $\mathrm{TSC}^{+/+}$ p53 ${ }^{-/-}$MEFs expressing TSC2 at high level [14], were transiently transfected with $p c D N A 3.1 / \mathrm{Myc}-\mathrm{PP} 5$ construct. Western blot analysis of cell lysates with specific antibodies confirmed the expression of recombinant Myc-PP5 (Fig. 1, A). Then, transfected cells were grown exponentially or serum starved for 24 hours, and afterwards, were stimulated with $10 \%$ FCS for one hour. The extracts were prepared from harvested cells and used in the immunoprecipitaiton assay. D6-TSC2 and anti-Myc antibodies were coupled
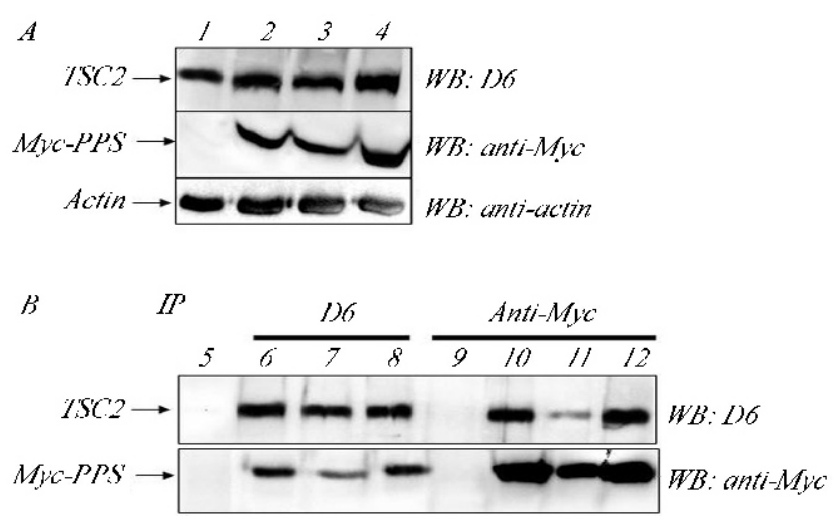

Fig. 1. Western blot analysis of TSC2 and PP5 in cell lysates $(A)$ and anti-D6 and anti-Myc immunoprecipitates $(B)$. TSC2 ${ }^{+/+} \mathrm{p} 53^{-/-} \mathrm{MEFs}$ were transiently transfected with $p c D N A 3.1$ (lanes 1,9) or pcDNA3.1/myc-PP5 (lanes 2-4, 5-8 and 10-12). Two days after transfection, TSC2 and Myc-PP5 were immunoprecipitated from cell extracts using mAb D6 (lanes 6-8) and anti-Myc (lanes 9-12). Protein A Sepharose was used to bring down immune complexes, which were then resolved by SDS-PAGE and immunoblotted with indicated antibodies. Cell lysates from $\mathrm{TSC}^{+/+} \mathrm{p} 53^{-/-} \mathrm{MEFs}$ were incubated with Protein A Sepharose without mAbs (lane 5); 1, 9 supernatant of exponentially growing $\mathrm{TSC}^{+/+} \mathrm{p} 53^{-/-}$MEFs, transiently transfected by $p c D N A 3.1 ; 6,10$ - supernatant of exponentially growing $\mathrm{TSC} 2^{+/+}, \mathrm{p} 53^{-/-} \mathrm{MEFs}$, transiently transfected by $p c D N A 3.1-P P 5-M y c ; 7,11$ - supernatant of serum starved $\mathrm{TSC}_{2}^{+++} \quad \mathrm{p}^{-/-} \quad \mathrm{MEFs}$, transiently transfected by pcDNA3.1-PP5-Myc; 8, 12 - supernatant of serum restimulated $\mathrm{TSC}^{+/+} \quad \mathrm{p}^{-/ /} \quad \mathrm{MEFs}$, transiently transfected by pcDNA3.1-PP5-Myc

to Protein A Sepharose and used to immunoprecipitate TSC2 and Myc-PP5 respectively. Immune complexes were separated by SDS-PAGE and analyzed by immunoblotting with specific antibodies.

As shown in Fig. 1, Myc-PP5 is detected in anti-TSC2 immune complexes and vise versa, TSC2 co-immunoprecipitates with Myc-PP5 in all analyzed samples. However, the interaction between Myc-PP5 and TSC2 was reproducibly weaker in serum starved cells, when compared to exponentially growing and serum-stimulated cells (Fig. 1, B, lanes $6-8$ and 10-12).

TSC1/2 complex is known to be a negative regulator of cell growth and mTOR signaling pathway. Therefore, its activity should be tightly controlled in growing and proliferating cells [2-6]. It is well established that several protein kinases phosphorylate TSC2 in vivo in response to various extracellular stimuli. For example, when cells are stimulated by growth factors or serum, the phosphophorylation of 
1

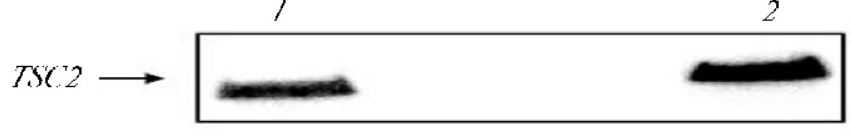

/

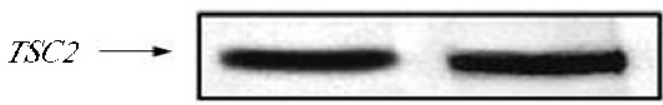

Figure 2. Dephosphorylation of TSC2 by recombinant PP5: $A-$ TSC2 was immunoprecipitated from cell lysates of exponentially growing $\mathrm{TSC}^{+/+} \mathrm{p} 53^{-/-}$MEFs and then phosphorylated by AMPK in in vitro kinase assay in the presence of $\left[\gamma-{ }^{32} \mathrm{P}\right] \mathrm{ATP}$. The reaction mixture was then incubated with (1) or without (2) recombinant PP5. After SDS-PAGE, the level of TSC2 phosphorylation was measured by autoradiography; $B$ - Western blot analysis of TSC2 protein by $\mathrm{D} 6 \mathrm{mAbs}$ in samples incubated with (1) or without (2) PP5

TSC 2 by PKB/Akt at several sites is known to inhibit its cellular functions.

On the other hand, AMP activated protein kinase (AMPK) is a cellular energy sensor and it plays an important role in the regulation of TSC2 activity [16]. AMPK-mediated phosphorylation of TSC2 at Ser 1345 induces its GAP activity towards small GTPase Rheb, resulting in its inactivation [8]. To explore a potential effect of PP5 on TSC2 phosphorylation status, we determine the phosphatase activity of PP5 towards TSC2 phosphorylated by AMPK.

In this analysis TSC2 was immunoprecipitated from exponently growing $\mathrm{TSC}^{+/+} \mathrm{p} 53^{-/-}$MEFs and then phosphorylated in vitro by AMPK kinase as described in «Materials and Methods». Then, pre-phosphorylated TSC2 was used as s substrate for PP5 in a phosphatase assay. According to the data presented in Fig. 2 PP5 reproducibly dephosphorylated TSC2 at AMPK specific sites.

To summarize, data presented in this report indicate that TSC2 interacts with PP5 in vivo and efficiency of such interaction depends on physiological status of cells. In addition, we demonstrated that PP5 is capable of dephosphorylating TSC2 in vitro at AMPK specific sites. Our data suggest that the physiological relevance of TSC2/PP5 interaction might be in reversing the stimulatory signaling mediated by AMPK on TSC2 activity.
Acknowledgements. The work of O. M. Malanchuk was supported by UNESCO fellowship.

О. М. Маланчук, С. С. Пальчевський, В. В. Філоненко

Серин/треонінова протеїнфосфатаза 5 дефосфорилює

туберозно-склерозний комплекс 2

Резюме

Вперше показано, що туберозно-склерозний комплекс 2 (TSC2) специфічно взаємодіє з протеїнфосфатазою 5 (РP5) у клітинах ссавиів. Така взаємодія є характерною для клітин, щзо перебувають у фазі експоненційного росту, а також $y$ стимульованих сироваткою клітинах. Встановлено, що РP5 дефосфорилює TSC2 по сайтах, специфічних для АМР кінази (AMPK) і відповідно може відігравати негативну роль у регуляиії активності TSC1/2 комплексу.

Ключові слова: серин/треонінова протеїнфосфатаза 5, туберозно-склерозний комплекс 2,дефосфорилювання.

\section{О. Н. Маланчук, С. С. Пальчевский, В. В. Филоненко}

Серин/треониновая протеинфосфатаза 5 дефосфорилирует туберозно-склерозный комплекс 2

Резюме

Впервые показано, что туберозно-склерозный комплекс 2 (TSC2) специфически взаимодействует с протеинфосфатазой 5 (PP5) в клетках млекопитающих. Данное взаимодействие является характерным для клеток, находящихся в фазе экспоненциильного роста, а также в стимулированных сывороткой клетках. Установлено, что РP5 дефосфорилирует TSC2 по сайтам, специфичным для АМР киназы (АМРК) и соответственно может играть негативную роль в регуляции активности TSC1/2 комплекса.

Ключевые слова: серин/треониновая протеинфосфатаза 5, туберозно-склерозный комплекс 2, дефосфорилирование.

\section{REFERENCES}

1. Barron R. P., Kainulainen V. T., Forrest C. R., Krafchik B., Mock D. G., Sandor K. B. Tuberous sclerosis: Clinopathologic features and review of the literature // J. Cranio-Maxillofac. Surg.-2002.-300.-P. 361-366.

2. Manning B. D., Cantley L. C. Rheb fills a GAP between TSC and TOR // Trends Biochem. Sci.-2003.- 28.-P. 573-576.

3. Gao X., Zhang Y., Arrazola P., Hino O., Kobayashi T., Yeung R. S., Ru B., Pan D. Tsc tumour suppressor proteins antagonize amino-acid-TOR signaling // Nat. Cell Biol.-2002.-4.-P. 699-704.

4. Saucedo L. J., Gao X., Chiarelli D. A., Li L., Pan D., Edgar B. $A$. Rheb promotes cell growth as a component of the insulin/TOR signalling network // Nat. Cell Biol.-2003.-5.-P. 566-571.

5. Stocker H., Radimerski T., Schindelholz B., Wittwer F., Belawat P., Daram P., Breuer S., Thomas G., Hafen E. Rheb is an essential regulator of $\mathrm{S} 6 \mathrm{~K}$ in controlling cell growth in Drosophila // Nat. Cell Biol.-2003.-5.-P. 559-565.

6. Hay N., Sonenberg N. Upstream and downstream of mTOR // Genes Develop.-2004.-18.-P. 1926-1945. 
7. Fingar D. C., Blenis J. Target of rapamycin (TOR): an integrator of nutrient and growth factor signals and coordinator of cell growth and cell cycle progression // Oncogene.-2004.-23.-P. 3151-3171.

8. Inoki K., Zhu T., Guan K. L. TSC2 mediates cellular energy response to control cell growth and survival // Cell.-2003.-115.-P. 577-590.

9. Ma L., Chen Z., Erdjument-Bromage H., Tempst P., Pandolfi $P$. $P$. Phosphorylation and functional inactivation of TSC 2 by Erk implications for tuberous sclerosis and cancer pathogenesis // Cell.-2005.-121.-P. 179-193.

10. Roux P. P., Ballif B. A., Anjum R., Gygi S. P., Blenis J. Tumor-promoting phorbol esters and activated Ras inactivate the tuberous sclerosis tumor suppressor complex via p90 ribosomal S6 kinase // Proc. Nat. Acad. Sci. USA.-2004.-101.-P. 13489-13494.

11. Hengstschlager M., Rodman D. M., Miloloza A., Hengstschlager-Ottnad E., Rosner M., Kubista M. Tuberous sclerosis gene products in proliferation control // Mutat. Res.-2001.-488.-P. 233-239.

12. Shamji A. F., Nghiem P., Schreiber S. L. Integration of growth factor and nutrient signaling: implications for cancer biology // Mol. Cell.-2003.-12.-P. 271-280.
13. Malanchuk O. M., Pozur V., Panasyuk G. G., Nemazanyy I. O., Filonenko V. V., Gout I. T., Palchevskyy S. S. Identification of novel binding partners for tuberous sclerosis complex 2 (TSC2) by yeast two-hybrid approach // Exp. Oncol.-2005.-27, N 3.-P. 186-190.

14. Malanchuk O. M., Palchevskyy S. S., Pozur V. K., Gout I. T., Filonenko $V$. $V$. Interaction of serine/threonine protein phosphatase 5 (PP5) with the protein product of tumour suppressor gene $T s c 2 / /$ Biopolymers and Cell.-2007.-29, N 4. - P. 318-323.

15. Malanchuk O. M., Palchevskyy S. S., Ovcharenko G. V., Gwalter J., Pozur V. K., Gout I. T., Filonenko V. V. Generation and characterization of monoclonal antibodies against tuberous sclerosis complex 2 // Hybridoma (Larchmt).-2007.-26, N 4. - P. 259-266.

16. Kah B. B., Alquier T., Carling D., Hardie D. G. AMP-activated protein kinase: ancient energy gauge provides clues to modern understanding of metabolism // Cell Metab.-2005.-1.-P. 15-25. 